\title{
Calcium Carbonate Cement: A Carbon Capture, Utilization, and Storage (CCUS) Technique
}

\author{
Craig W. Hargis ${ }^{1, *}$, Irvin A. Chen ${ }^{2}$, Martin Devenney ${ }^{2}$, Miguel J. Fernandez ${ }^{2}$, Ryan J. Gilliam ${ }^{1}$ \\ and Ryan P. Thatcher ${ }^{1}$ \\ 1 Fortera Corporation, 251 E. Hacienda Ave, Suite B, Campbell, CA 95008, USA; \\ rgilliam@forterausa.com (R.J.G.); rthatcher@forterausa.com (R.P.T.) \\ 2 Calera Corporation, Los Gatos, CA 95032, USA; irvinachen@gmail.com (I.A.C.); \\ mdevenney@gmail.com (M.D.); mfernandez@calera.com (M.J.F.) \\ * Correspondence: chargis@forterausa.com; Tel.: +1-669-267-6407
}

Citation: Hargis, C.W.; Chen, I.A.; Devenney, M.; Fernandez, M.J.;

Gilliam, R.J.; Thatcher, R.P. Calcium Carbonate Cement: A Carbon Capture, Utilization, and Storage (CCUS) Technique. Materials 2021, 14, 2709. https://doi.org/10.3390/ ma14112709

Academic Editor: Jorge S. Dolado

Received: 28 April 2021

Accepted: 20 May 2021

Published: 21 May 2021

Publisher's Note: MDPI stays neutral with regard to jurisdictional claims in published maps and institutional affiliations.

Copyright: (c) 2021 by the authors. Licensee MDPI, Basel, Switzerland. This article is an open access article distributed under the terms and conditions of the Creative Commons Attribution (CC BY) license (https:// creativecommons.org/licenses/by/ $4.0 /)$.

\begin{abstract}
A novel calcium carbonate cement system that mimics the naturally occurring mineralization process of carbon dioxide to biogenic or geologic calcium carbonate deposits was developed utilizing carbon dioxide-containing flue gas and high-calcium industrial solid waste as raw materials. The calcium carbonate cement reaction is based on the polymorphic transformation from metastable vaterite to aragonite and can achieve $>40 \mathrm{MPa}$ compressive strength. Due to its unique properties, the calcium carbonate cement is well suited for building materials applications with controlled factory manufacturing processes that can take advantage of its rapid curing at elevated temperatures and lower density for competitive advantages. Examples of suitable applications are lightweight fiber cement board and aerated concrete. The new cement system described is an environmentally sustainable alternative cement that can be carbon negative, meaning more carbon dioxide is captured during its manufacture than is emitted.
\end{abstract}

Keywords: cement; calcium carbonate; vaterite; carbon capture; industrial ecology

\section{Introduction}

Anthropogenic carbon dioxide $\left(\mathrm{CO}_{2}\right)$ is contributing to the rising atmospheric $\mathrm{CO}_{2}$ concentration, which is widely considered to be a leading contributing factor for the greenhouse effect, ocean acidification, and global climate change [1]. While efforts are being made to reduce $\mathrm{CO}_{2}$ emissions, global anthropogenic $\mathrm{CO}_{2}$ emissions are projected to continually increase over the coming decades, mainly driven by the growth of emerging countries [1-9]. Carbonate rocks are estimated to contain approximately 39,000,000 Gt of terrestrial $\mathrm{CO}_{2}$ and provide a potential pathway for stable, long-term storage of $\mathrm{CO}_{2}$ resulting from human activities [10]. Furthermore, carbonate rocks, such as limestone and marble, both mainly composed of calcium carbonate $\left(\mathrm{CaCO}_{3}\right)$, have long been widely utilized by mankind as construction materials, which offer a potential solution to upcycle the anthropogenic $\mathrm{CO}_{2}$ into value added materials [11].

$\mathrm{CaCO}_{3}$, one of the most abundant carbonate species in nature, has three anhydrous crystalline polymorphs: vaterite, aragonite, and calcite, with vaterite being the least and calcite being the most thermodynamically stable polymorph [12]. Calcite is the most abundant polymorph and is seen in geological formations, such as limestone, chalk, and marble of either biological or geological origin. Aragonite is less common, but abundant as oolitic sand in the Bahamas, while vaterite is observed much less often due to its instability in ambient conditions. However, in nature, many organisms, e.g., coral, first produce metastable amorphous $\mathrm{CaCO}_{3}$ as a precursor and control its transformation to aragonite or calcite to develop their rigid skeletons [13].

Inspired by the biological use of $\mathrm{CaCO}_{3}$, Fontaine et al. [14] and Combes et al. [15,16] successfully developed a $\mathrm{CaCO}_{3}$-based medical cement through an aqueous precipitation 
process using calcium chloride $\left(\mathrm{CaCl}_{2}\right)$ and sodium carbonate $\left(\mathrm{Na}_{2} \mathrm{CO}_{3}\right)$ as feedstocks. The cementing reaction is based on the polymorphic transformation from metastable amorphous $\mathrm{CaCO}_{3}$ and vaterite to aragonite or calcite through a dissolution-reprecipitation process in an aqueous medium. However, limited production scale and mechanical properties (3-13 MPa compressive strength) have restricted larger scale applications in the construction industry. Nevertheless, the results obtained by Combes et al. provide promising insights for the development of a nature inspired, synthetic $\mathrm{CaCO}_{3}$ cement system at scale from anthropogenic $\mathrm{CO}_{2}$ with properties suitable for various building materials applications.

Industrially, three feedstocks are required to produce $\mathrm{CaCO}_{3}$ cement: $\mathrm{CO}_{2}$, calcium, and alkalinity. $\mathrm{CO}_{2}$ can originate from $\mathrm{CO}_{2}$-containing industrial flue gas, e.g., thermal power plants, chemical plants, and cement kilns. Calcium and alkalinity can come from industrial waste streams that contain both calcium and alkalinity in the form of calcium oxide $(\mathrm{CaO})$, calcium hydroxide $\left(\mathrm{Ca}(\mathrm{OH})_{2}\right)$, and calcium silicates. Examples of calcium and alkalinity-rich industrial waste streams include: carbide lime sludge, an impure $\mathrm{Ca}(\mathrm{OH})_{2}$ by-product of producing acetylene gas $\left(\mathrm{C}_{2} \mathrm{H}_{2}\right)$ from coal and limestone, slag, a Ca/Mg-rich aluminosilicate glass by-product of iron and steel production, and cement kiln dust, an impure $\mathrm{CaCO}_{3} / \mathrm{CaO}$ by-product of Portland cement manufacturing that is often recycled in the cement kiln feed $[17,18]$. An acid can be utilized to extract the calcium from the waste feedstock and bring it into solution. Ammonium salts, e.g., ammonium chloride $\left(\mathrm{NH}_{4} \mathrm{Cl}\right)$, ammonium sulfate $\left(\left(\mathrm{NH}_{4}\right)_{2} \mathrm{SO}_{4}\right)$, and ammonium nitrate $\left(\mathrm{NH}_{4} \mathrm{NO}_{3}\right)$ have been shown to be effective acids in the production of vaterite from $\mathrm{CO}_{2}$ because they can bring the calcium into solution (Equation (1)), absorb $\mathrm{CO}_{2}$ from a gas stream (Equation (2)), and then be regenerated during the formation of $\mathrm{CaCO}_{3}$ (Equation (3)) $[17,19,20]$.

$$
\begin{gathered}
2 \mathrm{NH}_{4} \mathrm{Cl}_{(\mathrm{aq})}+\mathrm{CaO}_{(\mathrm{s})}+\mathrm{H}_{2} \mathrm{O}_{(\mathrm{l})} \rightarrow 2 \mathrm{NH}_{4} \mathrm{OH}_{(\mathrm{aq})}+\mathrm{CaCl}_{2(\mathrm{aq})} \\
2 \mathrm{NH}_{4} \mathrm{OH}_{(\mathrm{aq})}+\mathrm{CaCl}_{2(\mathrm{aq})}+\mathrm{CO}_{2(\mathrm{~g})} \rightarrow\left(\mathrm{NH}_{4}\right)_{2} \mathrm{CO}_{3(\mathrm{aq})}+\mathrm{CaCl}_{2(\mathrm{aq})}+\mathrm{H}_{2} \mathrm{O}_{(\mathrm{l})} \\
\left(\mathrm{NH}_{4}\right)_{2} \mathrm{CO}_{3(\mathrm{aq})}+\mathrm{CaCl}_{2(\mathrm{aq})} \rightarrow 2 \mathrm{NH}_{4} \mathrm{Cl}_{(\mathrm{aq})}+\mathrm{CaCO}_{3(\mathrm{~s})}
\end{gathered}
$$

To promote the formation of metastable forms of $\mathrm{CaCO}_{3}$ over calcite and aragonite, precipitation is performed at high reactant concentrations, needed to achieve high supersaturation and kinetic stabilization [21]. The concentration of carbonate ions is predominantly governed by (1) the rate of transfer of $\mathrm{CO}_{2}$ across the gas-liquid interface, (2) the rate at which $\mathrm{CO}_{2}$ converts into carbonate, and (3) the carbonate-bicarbonate equilibrium. The rate of mass transfer can be increased by increasing the flow rate of gas or by increasing the gas-liquid interface, for example by high shear mixing. Subsequent conversion of $\mathrm{CO}_{2}$ into carbonate can occur through the reaction with water $\left(\mathrm{H}_{2} \mathrm{O}\right)$ or hydroxyl ions $\left(\mathrm{OH}^{-}\right)$, but because the latter reaction is $10^{7}$ times faster, higher rates can be achieved by performing the reaction at higher $\mathrm{pH}$. Higher $\mathrm{pH}$ also favors higher equilibrium concentrations of carbonate over bicarbonate. Except for high gas flow rates, these strategies also improve the $\mathrm{CO}_{2}$ absorption efficiency.

Herein, a novel $\mathrm{CaCO}_{3}$ cement system that mimics the naturally occurring mineralization process of $\mathrm{CO}_{2}$ to biogenic or geologic $\mathrm{CaCO}_{3}$ deposits is described $[17,22]$. The $\mathrm{CaCO}_{3}$ cement is produced by capturing $\mathrm{CO}_{2}$-containing industrial flue gas and utilizing a calcium and alkalinity-rich industrial waste stream [18]. The result is a cement with a significantly lower $\mathrm{CO}_{2}$ and energy footprint compared to traditional inorganic binders, such as Portland cement. Furthermore, the $\mathrm{CaCO}_{3}$ cement offers processing and performance advantages in a variety of building materials applications over traditional inorganic binders.

\section{Materials and Methods}

\subsection{Raw Materials}

The carbide lime sludge (Gilmour \& Company, Inc., Vancouver, WA, USA) contained $25 \mathrm{wt} \%$ solids and had silica, alumina, and mixed oxidation state sulfur impurities, e.g., $\mathrm{S}^{2-}$ and $\mathrm{SO}_{4}{ }^{2-}$, see Table 1 . The $\mathrm{CO}_{2}$-containing flue gas used was generated from a boiler 
simulator (GE Energy and Environmental Research Corporation, Irvine, CA, USA) burning propane. $\mathrm{NH}_{4} \mathrm{Cl}$ (Zaclon, LLC, Cleveland, $\mathrm{OH}, \mathrm{USA}$ ) was used for solubilizing $\mathrm{Ca}(\mathrm{OH})_{2}$.

Table 1. Chemical composition of the oven-dried carbide lime sludge.

\begin{tabular}{cc}
\hline Oxide & Mass (\%) \\
\hline $\mathrm{CaO}$ & 70.0 \\
$\mathrm{SiO}_{2}$ & 2.4 \\
$\mathrm{Al}_{2} \mathrm{O}_{3}$ & 1.7 \\
$\mathrm{MgO}$ & 0.1 \\
$\mathrm{Fe}_{2} \mathrm{O}_{3}$ & 0.3 \\
$\mathrm{SO}_{3}$ & 0.7 \\
$\mathrm{MnO}$ & 0 \\
$\mathrm{TiO}_{2}$ & 0 \\
$\mathrm{P}_{2} \mathrm{O}_{5}$ & 0 \\
$\mathrm{Cl}^{1}$ & 0 \\
$\mathrm{LOI}^{1}$ & 24.4 \\
\hline
\end{tabular}

${ }^{1} \mathrm{LOI}$ is mass loss on ignition to $950^{\circ} \mathrm{C}$.

\subsection{Aqueous Mineralization Process}

To produce $\mathrm{CaCO}_{3}$ cement, the carbide lime sludge is first solubilized with aqueous $\mathrm{NH}_{4} \mathrm{Cl}$ then passed through a leaf filter to remove insoluble impurities resulting in an aqueous solution of $\mathrm{CaCl}_{2}$ and ammonia $\left(\mathrm{NH}_{3}\right)$, see Equation (1). $\mathrm{NH}_{3}$ dissolved in water is in equilibrium with ammonium hydroxide $\left(\mathrm{NH}_{4} \mathrm{OH}\right) . \mathrm{CO}_{2}$-containing flue gas $(11 \mathrm{vol} \%)$ is then contacted with the solution in a three-phase continuous-stirred tank reactor (CSTR) controlled at below $40{ }^{\circ} \mathrm{C}$ (Equation (2)), resulting in the precipitation of $\mathrm{CaCO}_{3}$ cement (Equation (3)). The simulated flue gas was blown from the boiler simulator to the absorber via a $20 \mathrm{~cm}$ steel pipe using a $600 \mathrm{cfm}$ roots style blower. Unlike some other carbon capture technologies, the $\mathrm{CO}_{2}$ does not need to be concentrated or compressed to high pressures for storage, which is energy intensive. The $\mathrm{CaCO}_{3}$ cement is then mechanically dewatered by a filter press (Outotec Oyj, Helsinki, Finland) and thermally dried in a swirl fluidizer (GEA Processing Engineering, Warrington, UK) to a free-flowing powder. The $\mathrm{NH}_{4} \mathrm{Cl}$ solution is recovered during dewatering and is recycled for the solubilization of additional carbide lime sludge. Insoluble impurities accounted for $7 \%$ of the dry mass of the carbide lime sludge and were composed of $70 \%$ mixed oxides and $30 \%$ carbon, see Table 1 . The insoluble impurities were treated as waste at the pilot plant, but, depending on the composition, could be used in industrial ecology applications, e.g., raw materials for Portland cement production or as supplementary cementitious materials [23]. Figure 1 shows a process block flow diagram of the $\mathrm{CaCO}_{3}$ cement manufacturing process. The $\mathrm{CaCO}_{3}$ cement pilot plant is shown in Figure 2.

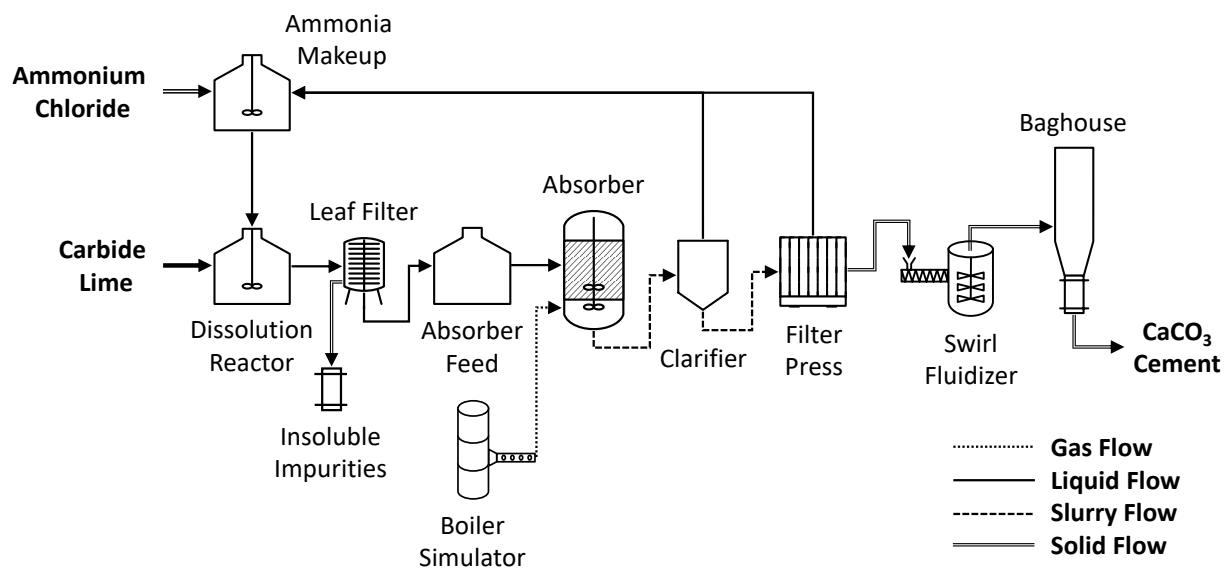

Figure 1. Block flow diagram of the $\mathrm{CaCO}_{3}$ cement manufacturing process. 


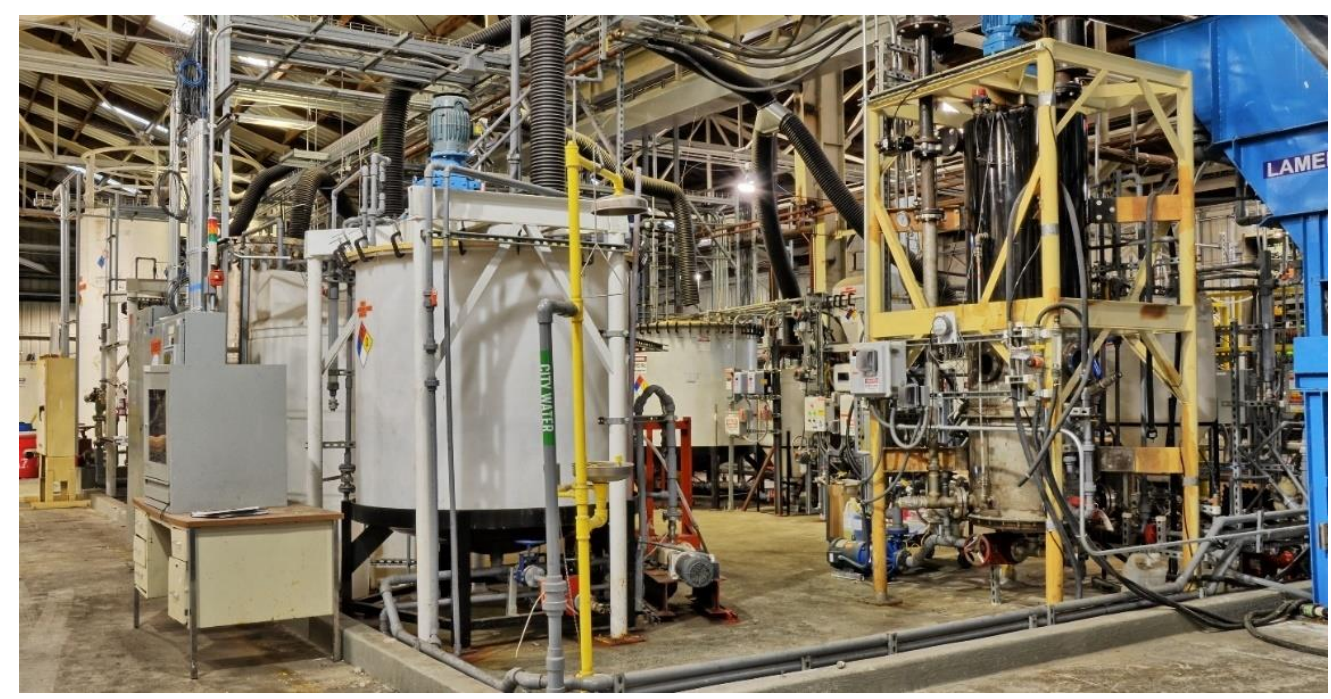

Figure 2. $\mathrm{CaCO}_{3}$ cement pilot plant.

\subsection{Analysis and Testing}

\subsubsection{Laser Particle Size Distribution}

A Horiba LA-950V2 Laser Scattering Particle Size Distribution Analyzer (two light sources: $650 \mathrm{~nm}$ wavelength laser and $405 \mathrm{~nm}$ wavelength LED) was used to study the particle size distribution of the $\mathrm{CaCO}_{3}$ cement. Measurements were carried out with test samples dispersed in isopropyl alcohol using refractive indexes of 1.378 for isopropyl alcohol and 1.58 for $\mathrm{CaCO}_{3}$.

\subsubsection{X-ray Florescence}

An ARL QUANT'X Energy Dispersive X-ray Fluorescence Spectrometer (Thermo Fisher Scientific, Waltham, MA, USA) was used to evaluate the chemical composition of the oven-dried raw materials and the $\mathrm{CaCO}_{3}$ cement. The loss on ignition (LOI) was determined by measuring the mass loss after heating the samples in an electric muffle furnace (Thermo Fisher Scientific, Waltham, MA, USA) at $950{ }^{\circ} \mathrm{C}$ for $60 \mathrm{~min}$.

\subsubsection{X-ray Diffraction}

A X'Pert Pro X-ray Diffractometer (Panalytical, Almelo, Netherlands) was used to determine the phase composition of the $\mathrm{CaCO}_{3}$ cement and the transformed cement pastes. The instrument was operated at $40 \mathrm{kV}$ and $30 \mathrm{~mA}\left(\mathrm{Cu} \mathrm{K} \mathrm{K}_{\alpha 1}, \lambda=1.5406 \AA\right)$ using a scan range of $5-65^{\circ} 2 \theta$, a step size of $0.02^{\circ}$, and dwell time of $4 \mathrm{~s}$. The resulting spectra were analyzed using Jade 9 software (Materials Data, Inc., Livermore, CA, USA) for qualitative phase composition information and MAUD software for quantitative Rietveld analysis (QXRD) [24].

\subsubsection{Scanning Electron Microscopy}

A SU-6600 Field Emission Scanning Electron Microscope (SEM) (Hitachi High-Tech, Omuta, Fukuoka, Japan) was used to collect images of the $\mathrm{CaCO}_{3}$ cement and the transformed cement paste. The samples were coated with platinum/palladium using a sputter coater (Electron Microscopy Sciences, Hatfield, PA, USA) prior to secondary electron imaging.

\subsubsection{Compressive Strength}

Compressive strength development of the $\mathrm{CaCO}_{3}$ cement was evaluated at $4 \mathrm{~h}, 10 \mathrm{~h}$, 1 day, 3 days, 7 days, and 14 days. Paste cubes $\left(50 \times 50 \times 50 \mathrm{~mm}^{3}\right)$ with a solution-to-solid ratio $(w / c)$ of 0.35 were utilized. The solution contained $0.1 \mathrm{M}$ magnesium and strontium chloride. The pastes were mixed according to ASTM C305 and then cast and compressed according to ASTM C109 $[25,26]$. The pastes cured inside brass cube molds at the specified 
temperature $\left(40,60\right.$ or $\left.80{ }^{\circ} \mathrm{C}\right)$ with $>95 \%$ relative humidity for up to 1 day. For testing between $4 \mathrm{~h}$ and 1 day, the paste cubes received no additional curing outside their molds. For 3-, 7-, and 14-day tests, the paste cubes were demolded at $24 \mathrm{~h}$ and placed in a bath with the same composition as the mix solution at the specified temperature $(40,60$, or $80^{\circ} \mathrm{C}$ ). The paste cubes were removed from their curing environments at the specified time and dried in a $105^{\circ} \mathrm{C}$ oven for $4 \mathrm{~h}$ before compressive strength testing with a loading rate of $1 \mathrm{kN} / \mathrm{s}$.

\section{Results}

\section{1. $\mathrm{CaCO}_{3}$ Cement Characteristics}

The $\mathrm{CaCO}_{3}$ cement has a median particle size of 15 with a $4 \mu \mathrm{m}$ standard deviation. The $\mathrm{D}_{90}$ and $\mathrm{D}_{10}$ for the $\mathrm{CaCO}_{3}$ cement are 19 and $11 \mu \mathrm{m}$, respectively. Figure 3 gives the particle size distribution of the cement. Individual crystals and small agglomerates make up less than $4 \%$ of the material at a median particle size of $0.4 \mu \mathrm{m}$. The primary nucleated crystals agglomerate in the CSTR to minimize their surface energy, forming a yarn-ball like, spherical morphology assembled of several microplates and lenses (Figure 4). Ammonium ions have been shown to promote the growth of vaterite into hexagonal plates and lenses by adsorbing onto the negatively charged (001) plane, which stabilizes the (001) face promoting the hexagonal crystal growth. Together with the oriented attachment of amorphous precursors and/or nanocrystals, the lens shaped single crystals are developed as the crystal grows [27-29]. In Figure 4, an individual lens can be observed above the right most vaterite sphere. In diffusion-based experiments, rosette mesostructures developed because the crystal structures were grown on a flat surface; whereas, in this study the mesostructures are spherical because the crystal agglomerates formed in solution.

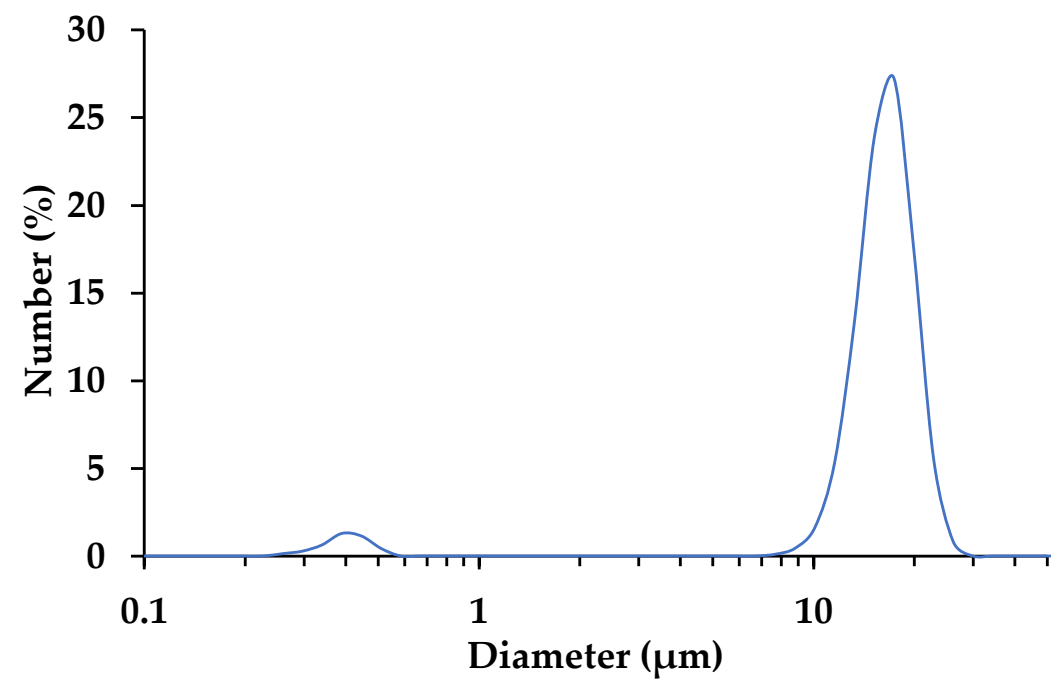

Figure 3. Particle size distribution of the $\mathrm{CaCO}_{3}$ cement.

Table 2 shows the chemical and mineral composition of the $\mathrm{CaCO}_{3}$ cement. The alumina and silica impurities found in the carbide lime sludge are not found in the resulting cement because they are relatively insoluble impurities that were removed during the filtering process (Figure 1); however, some magnesium and sulfate from the carbide lime sludge do make it into the resulting cement. The chloride in the cement comes from the $\mathrm{NH}_{4} \mathrm{Cl}$ solution. The mesostructure of the crystal agglomerates creates porosity and high surface area that traps solution. When the cement is heated and dried, the $\mathrm{NH}_{4} \mathrm{Cl}$ decomposes into hydrogen chloride $(\mathrm{HCl})$ and $\mathrm{NH}_{3}$ gas. The $\mathrm{HCl}$ and $\mathrm{NH}_{3}$ gas are recovered while scrubbing the flue gas. A portion of the $\mathrm{HCl}$ gas contacts water on the drying $\mathrm{CaCO}_{3}$, forming hydrochloric acid, and is neutralized by the $\mathrm{CaCO}_{3}$ cement, leaving a residual amount of $\mathrm{CaCl}_{2}$ [30]. The $\mathrm{CaCO}_{3}$ cement produced is mainly composed of metastable vaterite $(>99 \mathrm{wt} \%)$ with a minor amount of calcite $(<1 \mathrm{wt} \%)$, see Figure 5 . Formation of 
amorphous $\mathrm{CaCO}_{3}$ is deliberately avoided as it is difficult to stabilize and process on an industrial scale. Once the $\mathrm{CaCO}_{3}$ cement is dried, it is stable under ambient conditions.

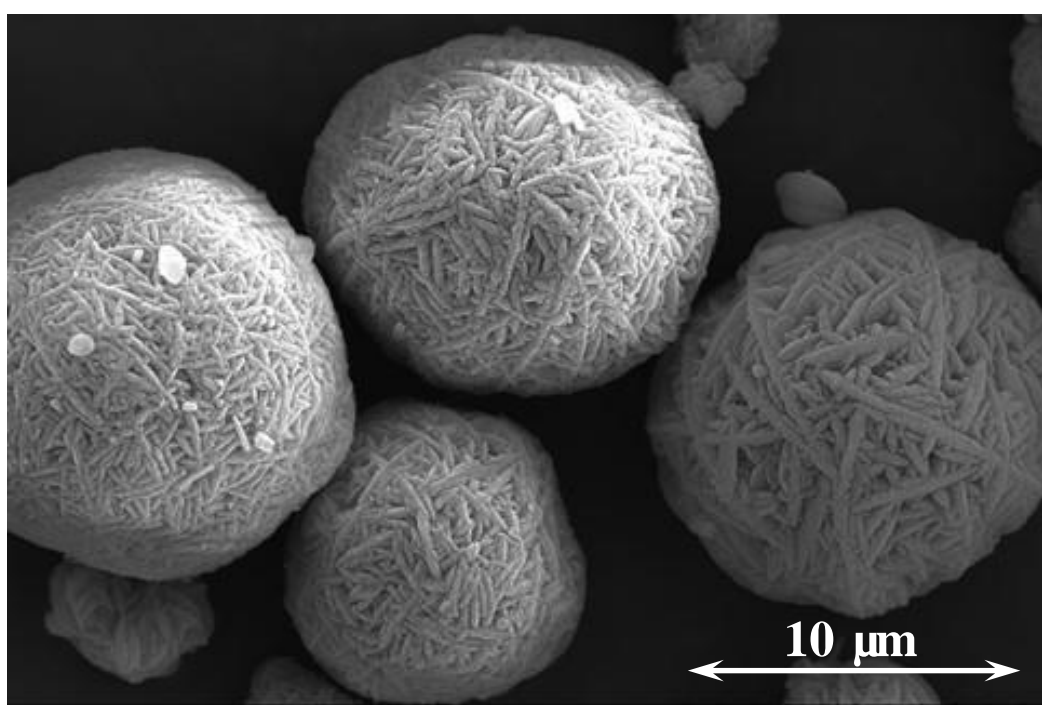

Figure 4. SEM image of the metastable $\mathrm{CaCO}_{3}$ cement (vaterite).

Table 2. Chemical (XRF) and mineral (QXRD) composition of the $\mathrm{CaCO}_{3}$ cement.

\begin{tabular}{cclc}
\hline Oxide & Weight (\%) & Mineral & Weight (\%) \\
\hline $\mathrm{CaO}$ & 55.1 & Vaterite & 99.5 \\
$\mathrm{SiO}_{2}$ & 0 & Calcite & 0.5 \\
$\mathrm{Al}_{2} \mathrm{O}_{3}$ & 0 & & \\
$\mathrm{MgO}$ & 0.1 & & \\
$\mathrm{Fe}_{2} \mathrm{O}_{3}$ & 0 & & \\
$\mathrm{SO}_{3}$ & 0.4 & & \\
$\mathrm{MnO}_{\mathrm{TiO}_{2}}$ & 0 & & \\
$\mathrm{P}_{2} \mathrm{O}_{5}$ & 0 & & \\
$\mathrm{Cl}$ & 0 & & \\
$\mathrm{LOI}^{1}$ & 0.2 & & \\
\hline
\end{tabular}

${ }^{1} \mathrm{LOI}$ is mass loss on ignition to $950{ }^{\circ} \mathrm{C}$.

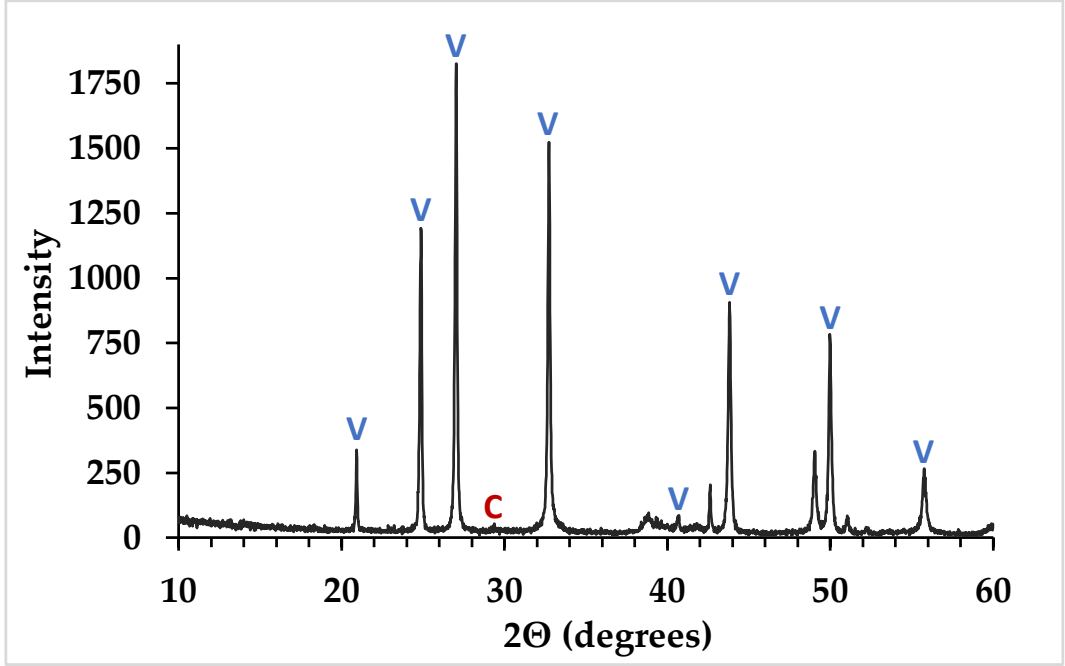

Figure 5. $\mathrm{XRD}$ pattern of $\mathrm{CaCO}_{3}$ cement $(\mathrm{V}=$ vaterite; $\mathrm{C}=$ calcite). 


\subsection{Cementitious Reaction}

The cementing reaction in $\mathrm{CaCO}_{3}$ cement is the transformation of vaterite $\left(\mathrm{CaCO}_{3}\right)$ to aragonite $\left(\mathrm{CaCO}_{3}\right)$ or calcite $\left(\mathrm{CaCO}_{3}\right)$. Vaterite dissolves and aragonite and/or calcite precipitates. Since the cementing reaction is an aqueous dissolution-reprecipitation process, curing the $\mathrm{CaCO}_{3}$ cement requires high humidity to maintain the transformation of vaterite to aragonite and/or calcite. If the humidity of the curing environment is not controlled, the material will desiccate, and the cementing reaction will cease, similar to Portland cement. Additionally, like Portland cement, the cementing reaction of $\mathrm{CaCO}_{3}$ cement can be accelerated by increasing the curing temperature. Figure 6 shows the temperature dependency of the $\mathrm{CaCO}_{3}$ cementing reaction and compressive strength development. The ultimate compressive strength of the material is $40 \mathrm{MPa}$, which is $3-13 \times$ higher than the 3-13 MPa compressive strength, previously reported for $\mathrm{CaCO}_{3}$ cement developed for medical applications [14,15]. At $40{ }^{\circ} \mathrm{C}, \mathrm{CaCO}_{3}$ cement paste does not show strength development through 1 day and takes 14 days to achieve the full strength. By elevating the temperature, full strength can be achieved by 7 or 3 days for 60 and $80^{\circ} \mathrm{C}$, respectively. Additionally, at elevated temperature, $\mathrm{CaCO}_{3}$ cement pastes have developed enough strength by 4 to $10 \mathrm{~h}$ ( 80 and $60{ }^{\circ} \mathrm{C}$, respectively) to be demolded and handled. Fast early strength is important for manufactured building materials with the need to transfer materials between initial and final curing steps, e.g., from pre-curing in molds at lower temperatures to autoclaving in stacks at elevated temperatures.

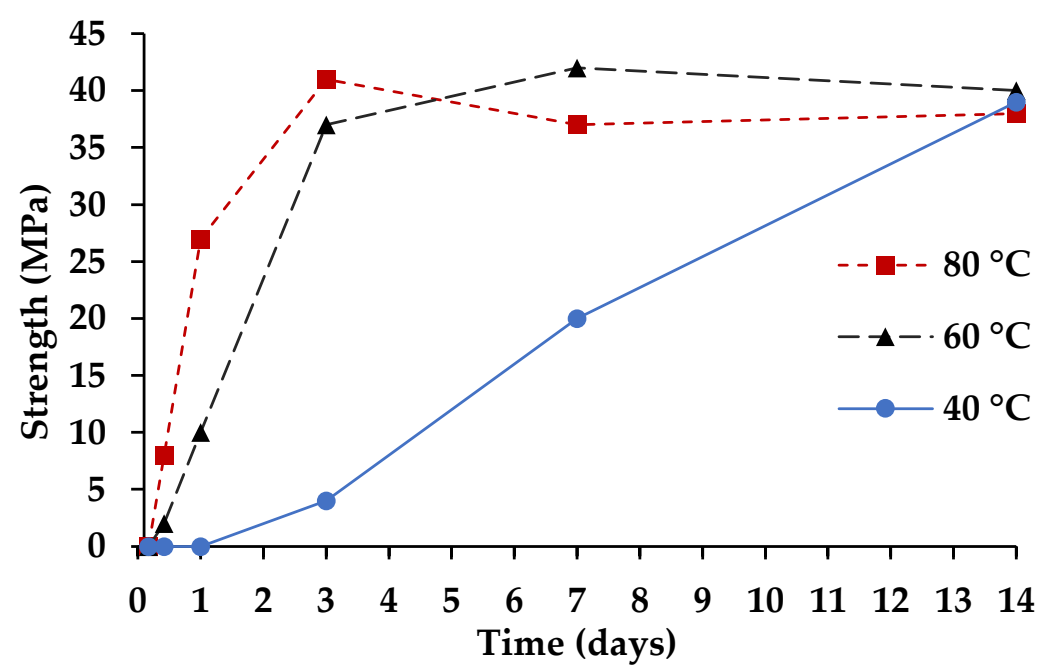

Figure 6. Temperature dependency of $\mathrm{CaCO}_{3}$ cement strength development.

During the dissolution of vaterite, aragonite is the preferred precipitate over the most thermodynamically stable calcite, as aragonite exhibits an acicular morphology which can lead to an interconnected microstructure. The formation of aragonite can be controlled through the use of magnesium-based additives (e.g., $\mathrm{MgCl}_{2}, \mathrm{MgSO}_{4}, \mathrm{Mg}\left(\mathrm{C}_{2} \mathrm{H}_{3} \mathrm{O}_{2}\right)_{2}$ ), which are known to inhibit calcite growth [31,32]. The size and aspect ratio of the acicular aragonite can be controlled by the use of strontium-based additives (e.g., $\mathrm{SrCl}_{2}, \mathrm{Sr}\left(\mathrm{C}_{2} \mathrm{H}_{3} \mathrm{O}_{2}\right)_{2}$ ), which are known to promote aragonite formation [33], resulting in thinner aragonite crystals with higher aspect ratios.

The interconnection of the aragonite crystals is controlled through the vaterite particle structure. The spherical vaterite particles have a large $(15 \mu \mathrm{m}$ median size $)$ and heterogeneous structure. At all curing temperatures, aragonite crystals nucleate on the surface of vaterite particles, then grow outward, which results in a dense and interconnected honeycomb microstructure (Figure 7). This phenomenon is consistent to Nielsen et al.'s [34] observation where they hypothesized that the phenomenon resulted from the high mobility and exchange of surface ions with solution. For the $\mathrm{CaCO}_{3}$ cement, water is only a medium for the metastable vaterite to dissolve and reprecipitate as aragonite and does 
not become chemically bonded. All the initial mix water will remain in the system after the cementing reaction and will become porosity after drying. Therefore, the cemented material is inherently more porous and less dense than traditional cements that are based on hydration reactions which chemically bind water. Furthermore, the pore solution of the $\mathrm{CaCO}_{3}$ cement paste is close to neutral compared to the alkaline traditional cements.

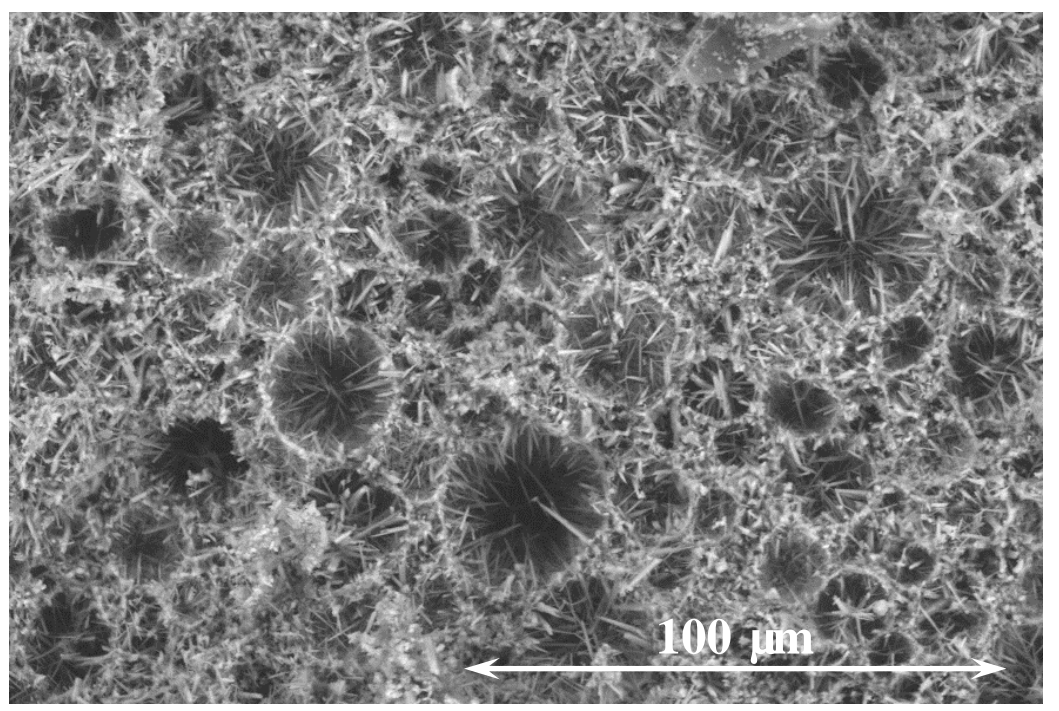

Figure 7. SEM image of the hardened cement paste (predominately aragonite).

Figure 8 shows the conversion of the $\mathrm{CaCO}_{3}$ cement (vaterite) to aragonite in the hardened cement paste. Comparing Figure 6 to Figure 8 elucidates that the cementing reaction and mechanical property development of the $\mathrm{CaCO}_{3}$ cement is entirely dependent on the vaterite to aragonite transformation, which is less complex than traditional cements and can be easily accelerated through temperature without negative effects on performance. For instance, at $80{ }^{\circ} \mathrm{C}$, the $\mathrm{CaCO}_{3}$ cement ( $99 \%$ vaterite and $1 \%$ calcite) has fully transformed to $98 \%$ aragonite and $2 \%$ calcite by 3 days of curing; whereas, at $40{ }^{\circ} \mathrm{C}$, the hardened cement paste is composed of $12 \%$ vaterite, $87 \%$ aragonite and $1 \%$ calcite at 14 days of curing.

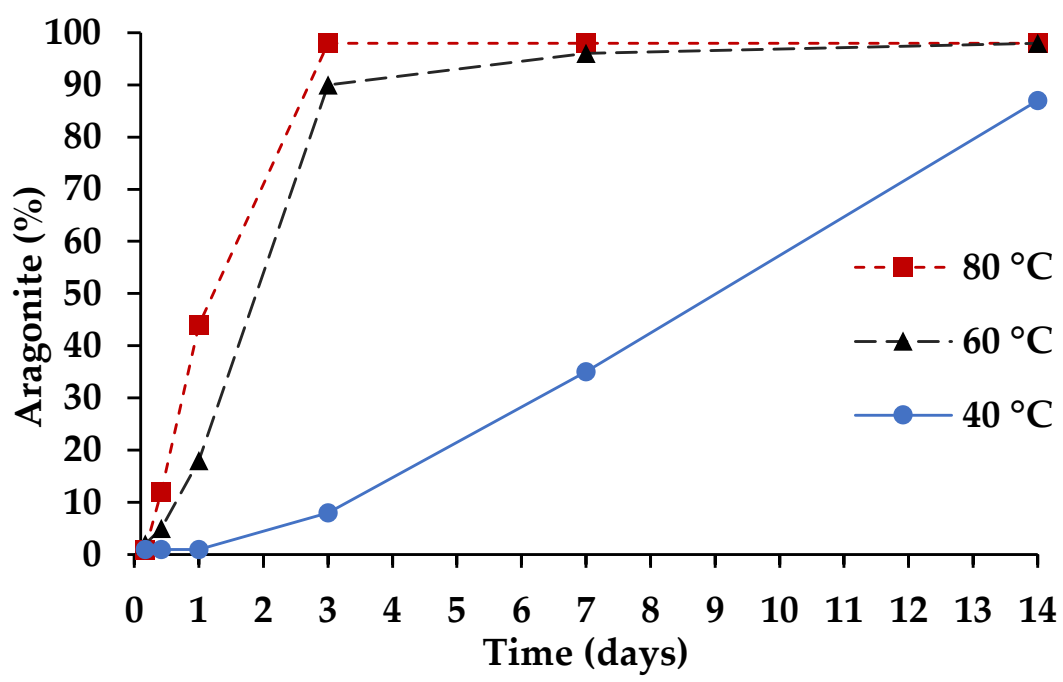

Figure 8. Conversion of $\mathrm{CaCO}_{3}$ cement to aragonite as a function of time and temperature (quantified by QXRD). 


\section{Discussion}

\subsection{Raw Materials Availability}

Annual global production of carbide lime sludge was estimated at approximately 25 million tons on a dry basis, where $>95 \%$ is generated in China [23]. Carbide lime sludge typically contains over $90 \mathrm{wt} \% \mathrm{Ca}(\mathrm{OH})_{2}$ on a dry basis with minor impurities such as carbon, silica, alumina, iron, and sulfur species depending on the composition of coal and limestone. Carbide lime sludge is used in China to replace limestone as a raw material for Portland cement production which can reduce $\mathrm{CO}_{2}$ emissions yet increase energy demand depending on the additional energy required to dry the carbide lime [35]. However, there is still a significant amount of carbide lime sludge being landfilled and legacy ponds, which cause major environmental issues due to carbide lime sludge's high alkalinity ( $\mathrm{pH}$ 12.4).

Iron and steel slag production is, on the contrary, more evenly distributed worldwide. It is estimated that about 510-664 million tons of iron and steel slag were generated annually in 2019 [36]. Iron and steel slags are composed of about $35-60 \mathrm{wt} \% \mathrm{CaO}$ with other constituents such as silica, alumina, magnesia, and sulfur species. Except ground granulated blast furnace slag, which is used as a supplementary cementitious material to replace Portland cement in mortar and concrete applications, most iron and steel slags are landfilled or can only be utilized in low-value applications such as road stabilization or asphalt aggregates [37]. Based on both the annual production of waste feedstocks (carbide lime sludge and iron and steel slag) and the $\mathrm{CaO}$ extraction efficiency, approximately 100 million tons of $\mathrm{CO}_{2}$ could be captured from industrial facilities and approximately 230 million tons of $\mathrm{CaCO}_{3}$ cement could be produced.

\subsection{Building Material Applications}

With its unique properties, $\mathrm{CaCO}_{3}$ cement is well suited for building materials applications with controlled factory manufacturing processes that are typically made from inorganic binders, such as Portland cement or gypsum. The $\mathrm{CaCO}_{3}$ cement can provide processing and performance advantages over Portland cement, e.g., shorter production cycles, lighter weight, and flexibility on fillers and reinforcement elements. Furthermore, $\mathrm{CaCO}_{3}$ cement is white, which makes it easy to color and texturize for decorative purposes.

Because of its neutral pore solution, $\mathrm{CaCO}_{3}$ cement is not suitable for structural applications that require mild steel reinforcement but is suited for composite systems development with the flexibility to incorporate a wide range of reinforcement elements for superior toughness and flexural properties. The neutral pore solution of the $\mathrm{CaCO}_{3}$ cement also makes it amenable for use in environmentally sensitive areas and applications that require biocompatibility.

$\mathrm{CaCO}_{3}$ cement's porosity has inherent advantages and disadvantages. The advantage is the ability to formulate lightweight products. For example, suitable potential applications are lightweight fiber cement board and autoclaved aerated concrete due to their manufacture in controlled environments that utilize elevated curing temperatures to accelerate property development. In other applications, the porosity could be a disadvantage, such as concrete in severe freeze-thaw or physical salt attack environments. The durability of $\mathrm{CaCO}_{3}$ cement in a range of situations and applications should be investigated in future research projects.

\section{3. $\mathrm{CaCO}_{3}$ Cement Manufacturing Energy and Carbon Footprint}

The $\mathrm{CaCO}_{3}$ cement manufacturing process (Figure 1) requires both electrical energy for mechanical processes (pre-processing, solubilization, filtration, $\mathrm{CO}_{2}$ capture, $\mathrm{CaCO}_{3}$ precipitation, dewatering, and aqueous recycling) and thermal energy for drying at approximately $130{ }^{\circ} \mathrm{C}$. Based on pilot plant data, production of $\mathrm{CaCO}_{3}$ cement is calculated to require 2.8 to $3.9 \mathrm{MJ} / \mathrm{kg}$ when considering a range of dry and wet raw materials. This compares to the 4.6 to $5.6 \mathrm{MJ} / \mathrm{kg}$ energy consumed during Portland cement production, mainly from the calcination of limestone at $900{ }^{\circ} \mathrm{C}$ and the sintering process at $1450{ }^{\circ} \mathrm{C}$ [38]. Since producing $\mathrm{CaCO}_{3}$ cement from waste feedstocks does not require high temperature 
processes and can capture and store $\mathrm{CO}_{2}$ from industrial emissions, $\mathrm{CaCO}_{3}$ cement has a significantly lower $\mathrm{CO}_{2}$ footprint compared to Portland cement. The energy and carbon footprint for $\mathrm{CaCO}_{3}$ cement manufacturing will vary for different sites and plant scales due to factors such as electricity mix, fuel sources, and operational efficiency.

For the highest energy consumption case $\left(3.9 \mathrm{MJ} / \mathrm{kg} \mathrm{CaCO}_{3}\right.$ cement), the electrical energy consumption is $92 \mathrm{kWh} /$ metric ton of $\mathrm{CaCO}_{3}$ cement, and the natural gas consumption is $3.57 \mathrm{GJ} /$ metric ton of $\mathrm{CaCO}_{3}$ cement. The plant operations that consume the most electricity are carbide lime sludge dissolution and filtration $(39 \%)$ and $\mathrm{CO}_{2}$ absorption including flue gas compression (38\%). $88 \%$ of the natural gas is consumed in the drying of the feedstock and product. Using a 2019 California grid carbon intensity of $175 \mathrm{~kg}$ $\mathrm{CO}_{2} / \mathrm{MWh}$, the electricity results in emissions of $16 \mathrm{~kg} \mathrm{CO} /$ metric ton of $\mathrm{CaCO}_{3}$ cement. With an emission factor of $56 \mathrm{~kg} \mathrm{CO}_{2} / \mathrm{GJ}$, the natural gas combustion produces $200 \mathrm{~kg}$ $\mathrm{CO}_{2} /$ metric ton of $\mathrm{CaCO}_{3}$ cement $[39,40]$. The total emissions are $216 \mathrm{~kg} \mathrm{CO}_{2} /$ metric ton of $\mathrm{CaCO}_{3}$ cement. Figure 9 compares the carbon captured and emitted during $\mathrm{CaCO}_{3}$ cement production to the $\mathrm{CO}_{2}$ emitted during Portland cement production. Since every metric ton of $\mathrm{CaCO}_{3}$ cement produced captures $440 \mathrm{~kg}$ of $\mathrm{CO}_{2}$ and manufacturing $\mathrm{CaCO}_{3}$ cement releases $216 \mathrm{~kg}$ of $\mathrm{CO}_{2}, \mathrm{CaCO}_{3}$ cement has a net capture of $224 \mathrm{~kg}$ of $\mathrm{CO}_{2} /$ metric ton of $\mathrm{CaCO}_{3}$ cement produced. Substituting $\mathrm{CaCO}_{3}$ cement for Portland cement, results in a reduction of $882 \mathrm{~kg}$ of $\mathrm{CO}_{2} /$ metric ton of cement utilized due to net emissions of $658 \mathrm{~kg}$ of $\mathrm{CO}_{2}$ avoided from Portland cement and a net capture of $224 \mathrm{~kg}$ of $\mathrm{CO}_{2}$ during the manufacture of $\mathrm{CaCO}_{3}$ cement when utilizing a waste $\mathrm{Ca}$ feedstock.

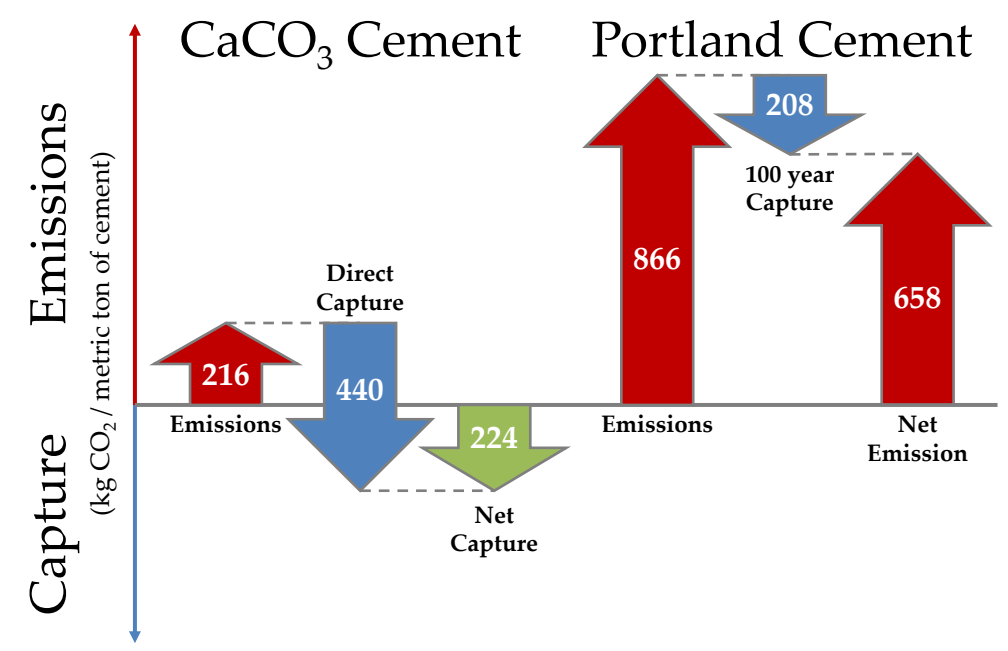

Figure 9. Carbon footprint of the pilot-scale $\mathrm{CaCO}_{3}$ cement manufacturing process compared to Portland cement manufacturing process (based on the upper range of energy consumption for the $\mathrm{CaCO}_{3}$ cement and average Portland cement emissions assuming $60 \%$ of emissions are from the calcination of limestone and $40 \%$ of those emissions are recaptured over 100 years [41-43]).

If curing is conducted at elevated temperature, additional energy input is required to heat the cementitious mixture to the curing temperature. For example, $1 \mathrm{~m}^{3}$ of concrete consisting of $305 \mathrm{~kg} \mathrm{CaCO}$ cement, $153 \mathrm{~kg}$ water, and $1978 \mathrm{~kg}$ of silicious aggregate requires $147 \mathrm{MJ}\left(0.48 \mathrm{MJ} / \mathrm{kg} \mathrm{CaCO}_{3}\right.$ cement) to heat from 20 to $80^{\circ} \mathrm{C}$. End of life uses for $\mathrm{CaCO}_{3}$ cement composites would be similar to those of Portland cement composites with the dominant recycling scheme being crushed into aggregate.

\section{Conclusions}

We have described a method of converting anthropogenic $\mathrm{CO}_{2}$ emissions into $\mathrm{CaCO}_{3}$ cement at a pilot scale. The $\mathrm{CaCO}_{3}$ cement gains approximately $40 \mathrm{MPa}$ of strength during its conversion from vaterite to aragonite, which is $3 \times$ higher than previously reported results. The cement paste hardens and gains strength through the formation of a network of interlocking aragonite needles. The conversion and strength gain can be accelerated by 
elevated curing temperatures, e.g., full conversion and strength in 3 days at $80^{\circ} \mathrm{C}$. The $\mathrm{CaCO}_{3}$ cement system is particularly well-suited in applications that can take advantage of the inherent porosity, low $\mathrm{pH}$, or rapid kinetics. The new cement system described is an environmentally sustainable alternative cement that can be carbon negative, meaning more $\mathrm{CO}_{2}$ can be captured during its manufacture than is emitted when utilizing a waste Ca feedstock.

Author Contributions: Conceptualization, I.A.C., M.D., M.J.F., R.J.G., C.W.H. and R.P.T.; methodology, I.A.C., M.J.F., C.W.H. and R.P.T.; formal analysis, I.A.C. and C.W.H.; investigation, I.A.C., M.D., M.J.F., R.J.G., C.W.H. and R.P.T.; resources, M.D. and R.J.G.; writing—original draft preparation, I.A.C. and C.W.H.; writing — review and editing, I.A.C., M.D., M.J.F., R.J.G., C.W.H. and R.P.T.; visualization, C.W.H.; supervision, M.D. and R.J.G.; project administration, I.A.C. and M.J.F.; funding acquisition, M.D. and R.J.G. All authors have read and agreed to the published version of the manuscript.

Funding: This material is based upon work supported by the U.S. Department of Energy, Office of Fossil Energy, under Award Number DE-FE-0002472.

Institutional Review Board Statement: Not applicable.

Informed Consent Statement: Not applicable.

Data Availability Statement: All research data are available and can be furnished upon request.

Acknowledgments: The authors express their thanks to their colleagues, scientific advisors, and investors for their dedicated support of the project. Appreciation for their assistance in conducting experiments is given to Patricia T. Lee, Samuel O. Morgan, Terilyn Q. Nguyen, Adrian Quiroz, and Chantel C. Tester. Finally, the authors thank Guillaume A. Calas and Michael J. Weiss for their assistance modeling the energy demand and $\mathrm{CO}_{2}$ emissions of the $\mathrm{CaCO}_{3}$ cement.

Conflicts of Interest: The authors declare no conflict of interest. The funders had no role in the design of the study; in the collection, analyses, or interpretation of data; in the writing of the manuscript, or in the decision to publish the results.

\section{References}

1. IPCC. Climate Change 2014: Synthesis Report. Contribution of Working Groups I, II and III to the Fifth Assessment Report of the Intergovernmental Panel on Climate Change; IPCC: Geneva, Switzerland, 2014; p. 151.

2. Akashi, O.; Hanaoka, T.; Matsuoka, Y.; Kainuma, M. A projection for global $\mathrm{CO}_{2}$ emissions from the industrial sector through 2030 based on activity level and technology changes. Energy 2011, 36, 1855-1867. [CrossRef]

3. Damtoft, J.; Lukasik, J.; Herfort, D.; Sorrentino, D.; Gartner, E. Sustainable development and climate change initiatives. Cem. Concr. Res. 2008, 38, 115-127. [CrossRef]

4. Gartner, E. Industrially interesting approaches to "low- $\mathrm{CO}_{2}$ " cements. Cem. Concr. Res. 2004, 34, 1489-1498. [CrossRef]

5. Gartner, E.; Hirao, H. A review of alternative approaches to the reduction of $\mathrm{CO}_{2}$ emissions associated with the manufacture of the binder phase in concrete. Cem. Concr. Res. 2015, 78, 126-142. [CrossRef]

6. Hargis, C.W.; Kirchheim, A.P.; Monteiro, P.J.M.; Gartner, E.M. Early age hydration of calcium sulfoaluminate (synthetic ye'elimite, C4A3\$) in the presence of gypsum and varying amounts of calcium hydroxide. Cem. Concr. Res. 2013, 48, 105-115. [CrossRef]

7. Hargis, C.W.; Telesca, A.; Monteiro, P.J. Calcium sulfoaluminate (Ye'elimite) hydration in the presence of gypsum, calcite, and vaterite. Cem. Concr. Res. 2014, 65, 15-20. [CrossRef]

8. Monteiro, P.J.; Clodic, L.; Battocchio, F.; Kanitpanyacharoen, W.; Chae, S.R.; Ha, J.; Wenk, H.-R. Incorporating carbon sequestration materials in civil infrastructure: A micro and nano-structural analysis. Cem. Concr. Compos. 2013, 40, 14-20. [CrossRef]

9. Hargis, C.W. Advances in Sustainable Cements, Doctoral Dissertation; University of California: Berkeley, CA, USA, 2013.

10. Oelkers, E.H.; Gislason, S.R.; Matter, J. Mineral Carbonation of $\mathrm{CO}_{2}$. Elements 2008, 4, 333-337. [CrossRef]

11. Freas, R.C.; Hayden, J.S.; Pryor, C.A., Jr. Limestone and dolomite in Industrial Minerals \& Rocks: Commodities, Markets, and Uses, 7th ed.; Society of Mining, Metallurgy and Exploration: Littleton, CO, USA, 2006.

12. Morse, J.W.; Arvidson, R.S.; Lüttge, A. Calcium carbonate formation and dissolution. Chem. Rev. 2007, 107, 342-381. [CrossRef]

13. Addadi, L.; Raz, S.; Weiner, S. Taking advantage of disorder: Amorphous calcium carbonate and its roles in biomineralization. Adv. Mater. 2003, 15, 959-970. [CrossRef]

14. Fontaine, M.-L.; Combes, C.; Sillam, T.; Dechambre, G.; Rey, C. New Calcium Carbonate-Based Cements for Bone Reconstruction. Key Eng. Mater. 2005, 284-286, 105-108. [CrossRef]

15. Combes, C.; Miao, B.; Bareille, R.; Rey, C. Preparation, physical-chemical characterisation and cytocompatibility of calcium carbonate cements. Biomaterials 2006, 27, 1945-1954. [CrossRef] [PubMed] 
16. Combes, C.; Tadier, S.; Galliard, H.; Fullana, S.G.; Charvillat, C.; Rey, C.; Auzely-Velty, R.; El Kissi, N. Rheological properties of calcium carbonate self-setting injectable paste. Acta Biomater. 2010, 6, 920-927. [CrossRef] [PubMed]

17. Devenney, M.; Fernandez, M.; Chen, I.; Calas, G. Methods and Systems for Utilizing Carbide Lime. U.S. Patent 9,902,652 B2, 31 July 2013.

18. Eloneva, S.; Teir, S.; Salminen, J.; Fogelholm, C.-J.; Zevenhoven, R. Steel Converter Slag as a Raw Material for Precipitation of Pure Calcium Carbonate. Ind. Eng. Chem. Res. 2008, 47, 7104-7111. [CrossRef]

19. Lee, M.-G.; Kang, D.; Yoo, Y.; Jo, H.; Song, H.-J.; Park, J. Continuous and Simultaneous $\mathrm{CO}_{2}$ Absorption, Calcium Extraction, and Production of Calcium Carbonate Using Ammonium Nitrate. Ind. Eng. Chem. Res. 2016, 55, 11795-11800. [CrossRef]

20. Udrea, I.; Capat, C.; Olaru, E.A.; Isopescu, R.; Mihai, M.; Mateescu, C.D.; Bradu, C. Vaterite Synthesis via Gas-Liquid Route under Controlled pH Conditions. Ind. Eng. Chem. Res. 2012, 51, 8185-8193. [CrossRef]

21. Zeebe, R.E.; Wolf-Gladrow, D. $\mathrm{CO}_{2}$ in Seawater: Equilibrium, Kinetics, Isotopes; Elsevier Science: Amsterdam, The Netherlands, 2001; Volume 65.

22. Fernandez, M.; Chen, I.; Lee, P.T.; Ginder-Vogel, M. Methods and Compositions Using Calcium Carbonate and Stabilizer. U.S. Patent 9,139,472 B2, 22 September 2015.

23. Asia Market Information \& Development Company. Chinese Markets for Calcium Carbide; Asia Market Information \& Development Company: Rockville, MD, USA, 2012.

24. Lutterotti, L.; Matthies, S.; Wenk, H.-R. MAUD: A friendly Java program for material analysis using diffraction. IUCR Newsl. CPD 1999, 21, 14-15.

25. ASTM. C109/C109M-13: Standard Test Method for Compressive Strength of Hydraulic Cement Mortars (Using 2-in. or [50-mm] Cube Specimens); ASTM: West Conshohocken, PA, USA, 2013; p. 10.

26. ASTM. C305-14: Standard Practice for Mechanical Mixing of Hydraulic Cement Pastes and Mortars of Plastic Consistency; ASTM: West Conshohocken, PA, USA, 2014; p. 3.

27. Gehrke, N.; Cölfen, H.; Pinna, N.; Antonietti, A.M.; Nassif, N. Superstructures of Calcium Carbonate Crystals by Oriented Attachment. Cryst. Growth Des. 2005, 5, 1317-1319. [CrossRef]

28. Hu, Q.; Zhang, J.; Teng, H.; Becker, U. Growth process and crystallographic properties of ammonia-induced vaterite. Am. Miner. 2012, 97, 1437-1445. [CrossRef]

29. Trushina, D.; Bukreeva, T.V.; Kovalchuk, M.V.; Antipina, M.N. $\mathrm{CaCO}_{3}$ vaterite microparticles for biomedical and personal care applications. Mater. Sci. Eng. C 2014, 45, 644-658. [CrossRef]

30. Popławski, D.; Hoffmann, J.; Hoffmann, K. Effect of carbonate minerals on the thermal stability of fertilisers containing ammonium nitrate. J. Therm. Anal. Calorim. 2016, 124, 1561-1574. [CrossRef]

31. Bischoff, J.L. Kinetics of calcite nucleation: Magnesium ion inhibition and ionic strength catalysis. J. Geophys. Res. Space Phys. 1968, 73, 3315-3322. [CrossRef]

32. Gutjahr, A.; Dabringhaus, H.; Lacmann, R. Studies of the growth and dissolution kinetics of the $\mathrm{CaCO}_{3}$ polymorphs calcite and aragonite II. The influence of divalent cation additives on the growth and dissolution rates. J. Cryst. Growth 1996, 158, 310-315. [CrossRef]

33. Bischoff, J.L. Catalysis, inhibition, and the calcite-aragonite problem; II. The vaterite-aragonite transformation. Am. J. Sci. 1968, 266, 80-90. [CrossRef]

34. Nielsen, M.H.; Aloni, S.; De Yoreo, J.J. In situ TEM imaging of $\mathrm{CaCO}_{3}$ nucleation reveals coexistence of direct and indirect pathways. Science 2014, 345, 1158-1162. [CrossRef]

35. Sun, B.; Liu, Y.; Nie, Z.; Gao, F.; Wang, Z.; Cui, S. Exergy-based resource consumption analysis of cement clinker production using natural mineral and using calcium carbide sludge (CCS) as raw material in China. Int. J. Life Cycle Assess. 2020, $25,667-677$. [CrossRef]

36. USG Survey. Mineral Commodity Summaries: Iron and Steel Slag; USGS: Lakewood, CO, USA, 2020.

37. Ahmedzade, P.; Sengoz, B. Evaluation of steel slag coarse aggregate in hot mix asphalt concrete. J. Hazard. Mater. 2009, 165, 300-305. [CrossRef]

38. Hewlett, P.C.; Soutsos, M.; Domone, P. Construction Materials: Their Nature and Behaviour, 5th ed.; Soutsos, M., Domone, P., Eds.; CRC Press: Boca Raton, FL, USA, 2017; ISBN 978-1498741101.

39. EIA Carbon Dioxide Emissions Coefficients. Available online: https://www.eia.gov/environment/emissions/co2_vol_mass.php (accessed on 14 May 2021).

40. EPA eGRID Data Explorer. Available online: https:/ / www.epa.gov/egrid/data-explorer (accessed on 14 May 2021).

41. Barcelo, L.; Kline, J.; Walenta, G.; Gartner, E. Cement and carbon emissions. Mater. Struct. 2013, 47, 1055-1065. [CrossRef]

42. World Business Council for Sustainable Development. Cement Industry Energy and $\mathrm{CO}_{2}$ Performance, Getting the Numbers Right; CSI: New York, NY, USA, 2009.

43. Pade, C.; Guimaraes, M. The $\mathrm{CO}_{2}$ uptake of concrete in a 100 year perspective. Cem. Concr. Res. 2007, 37, 1348-1356. [CrossRef] 